New Zealand journal of industrial relations, 1984, 9, 177-193

\title{
Towards the automated office: technological change and office work in the New Zealand Public Service
}

\author{
Paul K Couchman *
}

This paper examines Braverman's theory of the labour process in relation to the historical transformation of office work in the New Zealand Public Service. It focuses upon two exclusively female occupations, those of typist and secretary. The paper also examines the range of control strategies available to management; conflicts between groups of employees; and technological change as a political process.

\section{Introduction}

The question Braverman (1974) sought to answer, is why production technology has developed in the way that it has. According to him, it is in the interests of the accumulation of capital that employers seek to maximise control over their employees. As employees sell to employers "... not an agreed amount of labour but the power to labour over an agreed period of time", the employer is faced with the problem of translating this labour power into labour. In a setting of antagonistic relations, this is the managerial problem of control. In enterprises under monopoly capitalism, managerial control over the production process is achieved through the application of the principles of "scientific management" and through technological change, thereby deskilling work which is progressively "degraded" (for a more detailed statement of Braverman's thesis, see Brocklesby, 1983).

This paper takes Braverman's perspective as a starting point. Although widely praised, there have been many critiques of his analysis (for example Burawoy, 1978; Beechey, 1979; Elger, 1979; Stark, 1980; Littler, 1982; Wood, 1982), and it is considered not to be adequate as an explanatory framework. The following paper examines Braverman's thesis in relation to the historical transformation of office work in the New Zealand Public Service, and focuses on 2 exclusively female occupations within this, those of typist and secretary. These occupations were created following the introduction of the first machines into the office (the "first wave" of technological change in the office), but they are now facing significant transformation with the advent of word processors and the prospect of the automated office (the "second wave" of technological change).

The discussion centres around 3 themes, which represent extensions of Braverman's framework:

(1) a range of control strategies (not merely that identified by Braverman) is available to managers - in the Public Service the most important control strategy is the use of bureaucratic rules and regulations;

* Social Scientist, Social Science Section, DSIR, Wellington.

I would like to acknowledge gratefully the constructive comments made on earlier drafts of this paper by the other symposium participants, the journal editors, Joanna Beresford (PSA) and Paul Harris (PSA). 
(2) Braverman focuses on the conflict of interests between employer and employee, but conflicts also exist among different groups of employees. Occupations within the Public Service Office workforce have been segregated (both vertically and horizontally) by sex, creating 2 hierarchies of office workers;

(3) Braverman depicts employers as imposing managerial policies on a "virtually inert working class" (Elger, 1979, p. 60), but technological change in the workplace is a political process, and employees are by no means acquiescent in the face of managerial initiatives.

The 2 waves of technological change and their effects on office work are first described, then recent responses to the new office technologies in the Public Service are outlined. The paper concludes with a discussion, centred on the above 3 themes, of these changes, and the implications of the case study for Braverman's theoretical framework.

\section{The transformation of office work in the Public Service}

The late 19th and early 20 th century saw a radical transformation in office work within the Public Service. In the mid-19th century, government offices were small, allmale, and the clerks employed therein were "all round" workers - each performed a variety of tasks under the supervision of the "master craftsmen" (i.e. the book-keepers and chief clerks). This was true of office work generally in the economy, and the total clerical workforce was very small (at the 1874 Census, of the Europeans actively engaged in the workforce only around 3 percent were in clerical occupations).

In the latter part of the 19 th century this situation started to change with the growth of capitalist enterprises (both in size and number), and as Government expanded into new areas of activity. The Government began to take a more active role in social and economic life, so the size and number of government agencies increased: between 1869 and 1900 , 14 new departments were created as the Government became involved in such areas as life insurance, the provision of education, the collection of income tax, and the provision of social welfare and public health services (Polaschek, 1958). Accompanying this growth were 3 other major changes:

\section{Bureaucratisation}

During the 19th century relations within government offices were personalised and informal. Although some bureaucratic rules and regulations governing the activities of public servants existed, control in departments mostly took the form of face-to-face "simple control", with little uniformity in the way power was exercised and with employees often being treated arbitrarily. From the mid-19th century a number of attempts were made to reform the Public Service and create a formal bureaucratic organisation (Polaschek, 1958), but it was not until 1912 - with the passage of the Public Service Act - that this was achieved.

This Act, and the Regulations made under it, provided for the impersonalised and standardised control over the activities of employees, and introduced the main features of a bureaucratic organisation (Weber, 1964) to the Public Service. Officials were made subject to a unified control and disciplinary system under the authority of a Public Service Commissioner (whose role was ". . . to ensure the establishment and continuance of a proper standard of efficiency and economy in the Public Service "). The Service was classified into 4 divisions (administrative, professional, clerical, and general), and each of these was subdivided into classes with prescribed salary scales. The Clerical Division was divided into 8 classes, each with a specified range of salaries; annual increments within classes were automatic up to the maximum provided, but there were efficiency bars for the junior grades. Qualifications for entry into the various divisions of the Service were set down, as were the conditions for promotion and dismissal. Thus, the Act provided a 
career for employees within the Public Service with, for most at least, the opportunity for upward mobility through an hierarchy of graded positions.

But the Act also made provision for temporary employment. The Act empowered the Commissioner to appoint temporary staff in cases of necessity. The term of employment for these was finite, and they had few of the rights of permanent employees.

\section{Mechanisation - the "first wave" of technological change}

The first mechanisation of office work was that of the writing task, which followed the commercial production in the mid-1870s of the Sholes and Glidden typewriter (Beeching, 1974). Shortly after this a wide range of other machines was introduced into the office, for example, telephones, dictation machines, copiers, calculating machines, book keeping machines, etc. Prior to the introduction of typewriters, all transcription of information (i.e. the recording and copying of letters, notes, minutes, contracts, reports, etc.) was by hand, the necessary tools being only pens, ink, pencils, writing paper, envelopes and ledgers. Shorthand-writing was a necessary and important skill in the office (Anderson, 1976), and this was recognised in the Public Service, (e.g shorthand writing was prescribed as an optional subject for the Entrance Examination, and officers in the junior grades of the Clerical Division could gain 6 months' seniority by passing shorthand at 100 words per minute and typing at 40 words per minute). But with the introduction of stenography and dictation machines, the need for this skill was decreased. The specialist clerical occupation of "shorthand writer" existed alongside that of typist (or "typewriter") well into the 20 th century, but it gradually became absorbed into the typist's function.

In conjunction with a technical division of labour, the introduction of the typewriter facilitated the separation of "mental work" from "manual work" in the office. Two occupational hierarchies developed (Glenn and Feldberg, 1979):

(1) an administrative hierarchy whose work centred on conception (i.e. creating information and controlling the processing of information);

(2) an hierarchy of detail workers who were concerned exclusively with execution (i.e. the recording, copying and filing of information).

There was a tendency to progressively eliminate the need to think from the work of those in the latter hierarchy. In the task of typing, mental processes were reduced to so small a factor in the work process, that the speed and dexterity with which the manual part of the operation could be performed dominated the whole process. This was particularly the case in the typing pool, a separate production section within a department, in which the sole task of employees was to mechanically transcribe copy (this is "manual work" compared with "mental work" of creating copy) from hand-written or dictated material. Mental work in this situation was not entirely eliminated, however. The typewriter is a machine which operates at the level of a hand-tool and is under the direct control of its operator. Some control over the work and the way it was done therefore remained with the typists, but even this control could be eroded with the introduction of standardised formats for reports and correspondence. 
workers include managers, administrators, engineers, scientists, and other office workers who are engaged in "mental work". The introduction of word processing was aimed at reducing the costs of secretarial and typing work in the office, but these tasks account for only a very small proportion of total office labour costs. The great bulk of such costs are those of knowledge workers. Office automation is thus promoted as increasing the productivity of these workers (Tapscott, 1981; p. 20):

Three-quarters of total office labour costs are spent on the knowledge workers. It is the managers ... and other professional and technical people working with their minds, who are the fastest-growing sector of the overall labour force. And it is in the augmentation of their abilities and effectiveness that the greatest potential of office automation is contained.

The driving forces behind the development of the automated office have been identified to be a combination of "technology push" (i.e. technological developments in the areas of micro-electronics and telecommunications) and "demand pull", the latter stemming from a desire to restrain the growth of office costs and the need to manage the rapidly expanding resource of information. The hardware of new office technology has resulted from the progressive cheapening of micro-electronic technology and the convergence of what had been 3 separate areas of technology: data processing, office technologies, and communication technologies. The integration of these has resulted in the "electronic desk" (Spinrad, 1982). This has its own computational, information storage and communications capabilities. It can be linked into an intra-office network which has a central data file and printing facilities, and through a "communications server" to other networks. It is envisaged that the electronic desk will enable knowledge workers to process all their own work, with the necessary support provided only by the technology.

The capabilities of the automated office could significantly transform the nature of office work. Many of the tasks performed by detail workers (e.g. filing, transcribing, copying, mail sorting and delivery, etc.) could be progressively eliminated, and the work of those engaged in mental work could be considerably reorganised. The concept of office automation is still a new one in New Zealand, and its implications for the office workforce have only been the subject of discussion over the last 3-4 years (e.g. Beardon, 1981; Sutherland, 1981; Public Service Association, 1980, 1981). One area where the new office technology could make a significant impact is the Public Service, and within this the first group of employees to be affected are the typists.

New technology and the Public Service

The prospect of the automated office presents a challenge to the clerical workforce (and particularly to the lower-graded clerical employees, office assistants and typists: most of the first group are women, as are virtually all of the employees in the other 2 occupations) and its trade unions (Gregory and Nussbaum, 1982). In the Public Service, the first effects of the second wave of technological change have only recently started to be felt in most offices. The first word processors in the Public Service were introduced in the mid-1970s (these were non-VDU work stations). By mid-1980, 14 out of 35 departments had at least one word processing system, and by March 1982 this had increased to 30 departments (State Services Commission, 1983). An investigation of the use of word processors in departments (State Services Commission, 1980) revealed that, using this technology, more typing was being carried out using the same number of typists. Although no typists had been made redundant as a result of the introduction of word processors, a number of departments had been able to reduce the number of typists through natural attrition while coping with the same or increased workloads.

These observations are confirmed by a comparison of the numbers of typists employed in the Public Service with the numbers employed in those occupations which create most of the copy for typing, as shown in Table 2. During the period in which word processors were introduced, there was a decline in the number of typists relative to the copy pro- 
ducers (this trend commenced prior to the introduction of word processors). Whereas the number of permanent employees in the copy-producing occupational classes increased by an average of 4.1 percent p.a. over the period 1970 - 1983 (i.e. from 21537 to 32892 ), the number of typists increased at an average of only 0.9 percent p.a. (i.e. from 2712 to 3034). The ratio of copy producers to typists has therefore increased from 7.94 in 1970 to 10.84 in 1983 . Furthermore, in terms of numbers employed, the typing occupational class has started to decline: from a maximum of 3108 persons in 1981, to 3034 in 1983 . Thus, if the output of typing copy per employee has remained more or less the same over this period, fewer typists are now coping with more work. It is very likely that the new technology has played a role in this increased productivity.

\section{Responses to the challenge of new technology in the office}

A major weakness of Braverman's analysis appears to be that he treated the workforce ". . . as an unproblematic and totally acquiescent presence in the labour process" (Wilkinson, 1983). But, on the contrary, the introduction of the new technology has not been marked by passive acquiescence of the workforce. In the case of in the Public Service, attempts have been made through the trade union - the Public Service Association (PSA) - to influence the decisions on the deployment of word processors and other new office technologies.

\section{Increasing awareness of the new technology}

A Public Service Association was formed in 1890, but this soon went out of existence (Robertson, 1974), and there was no collective resistance to the first wave of technological change in the office. The second wave of technological change, however, has been of concern to the PSA (re-established in 1913). At its 1979 Annual Conference, the Association adopted a policy on new technology which emphasised the need for:

(1) consultation prior to the introduction of new technology;

(2) negotiation on the effects of new technology in the workplace;

(3) the right of employees displaced by new technology to be redeployed and/or retrained.

Table 2: Typists and typing copy producers on the permanent staff of the State Services at 31 March each year, $1970-1983$

\begin{tabular}{lccc}
\hline Year & $\begin{array}{c}\text { No. } \\
\text { Typists }\end{array}$ & $\begin{array}{c}\text { No. } \\
\text { Copy Producers* }\end{array}$ & $\begin{array}{c}\text { Ratio } \\
\text { Producers per Typist }\end{array}$ \\
\hline 1970 & 2712 & 21537 & 7.94 \\
1975 & 2910 & 27122 & 9.32 \\
1980 & 3091 & 31607 & 10.23 \\
1981 & 3108 & 32502 & 10.46 \\
1982 & 3084 & 32719 & 10.61 \\
1983 & 3034 & 32892 & 10.84 \\
\hline
\end{tabular}

Source: Annual Reports of the State Services Commission (G.3)

* This is the number employed in the 35 occupational groups which together generate most of the typing copy (i.e. excludes those which produce, if any, only a very small proportion of the total copy; e.g. telephone operators, trades group, nursing, machining, etc.). 
The PSA has been involved in 2 main types of activity in relation to the new technology. The first type is the dissemination of information (i.e. by way of talks, articles in the Public Service Journal, information leaflets, and research discussion papers), aimed at heightening awareness among employees of the issues involved. The concerns of the Association have been stated in one of its information leaflets (Public Service Association, 1983):

Why should unions be concerned about new technology? Unions are concerned because it destroys jobs, it de-skills jobs and drastically alters job content and it may affect workers' health and safety. It also creates benefits which should be shared by the workers who use the new equipment and machinery instead of all the benefits going to those who own it.

The second type of activity is bargaining on the introduction of new technology with the State Services Commission.

\section{Bargaining on new technology in the Public Service: the case of typists}

The introduction of word processors marks the beginning of the second wave of technological change in the office, and the first group of employees to be directly affected by this is the typists. Bargaining has sought both to protect and enhance the career prospects for typists, and to influence the deployment of the new technology.

Although many occupational groups, including that of shorthand-typist, had been recognised for bargaining purposes in the Public Service, it was not until after the State Services Act 1962 that a Typing Occupational Class was formally created. This occupational class, and the conditions prescribed for its members, remained more or less the same until the PSA lodged a salary claim for it in August 1977. The basis for the claim was that there was an inadequate career structure for typists in the Public Service, and that members of the occupational class were not given the opportunity for advancement that employees in other classes were. The claim was eventually settled on 30 August 1978 with a determination which restructured the typing occupational class and defined 5 typists' designations (i.e. typist trainee, staff typist, senior typist, supervisory typist, and supervising-typist-in-charge).

Of particular signficance was that job descriptions for each of the 4 main designations were agreed to, and these specified 2 levels of responsibility for word processing (although word processor operators were not designated as such). Thus, the main duties of a staff typist could include "... rudimentary word processing as directed" and it was for senior typists to carry out ". . . more advanced and complex word processing." This was the first time that the new technology was given formal recognition in an agreement between the PSA and the SSC.

In August 1981, another claim was made for the typists. The basis for this was that career prospects for typists in the Public Service had not improved since the 1978 determination, and one of the causes was believed to be that the existing job descriptions did not sufficiently differentiate between the various levels of skill and responsibility within the occupational class. This was the case for word processing, and it was maintained that the additional skills required for their operation should be recognised by higher grading. A new set of job descriptions (which did take into account the different levels of skill required) was therefore proposed, but the settlement determination in February 1982 did not include these.

During negotiations on this claim, the Commission indicated that a working party would be a more appropriate forum in which to discuss job descriptions. This was agreed to by the PSA, who wanted to widen the scope of the working party's brief to consider ways and means of improving the career prospects of typists, but after discussion it was decided that the working party would focus on the definition of suitable job descriptions. The working party of 6 women, consisting of equal numbers representing the SSC and the 
PSA, first met in February 1982.

The working party released a report (the second of 2 parts) on word processing in December 1983. The working party considered that word processing skills were an extension of the typists' conventional keyboard and other skills, and that the pay of word processor operators and supervisors should reflect this. The skill differentials involved in word processing were incorporated into the proposed job definitions. Four levels of word processor operator were defined. The bottom level was for trainee operators, i.e. typists with sufficient experience to be proficient in normal departmental typing duties and who are required to learn to use word processors. The top level was for those operators engaged in the most skilled tasks, including developmental work (it was noted that there was little of this type of work being done by Public Service typists at present but some operators could be engaged on it in the future).

The working party's recommendations on word processing have yet to be acted on by the State Services Commission, so they have had no effect on Public Service typists. However, negotiations between the PSA and the SSC during 1981 resulted in the drafting of an agreement on the introduction of visual display units (VDUs) into the Public Service. The basis of this agreement is stated in its preamble (PSA, 1982):

The PSA and SSC both recognise that VDUs have become indispensable equipment in many workplaces and that their use will become more widespread in the future. Both parties are agreed that they are a desirable tool contributing to the efficiency of the Public Service and that as such it is necessary to ensure that they are introduced in an orderly manner with due account being taken of the health, comfort and well-being of the staff affected. Furthermore, this equipment should be introduced in such a manner as to be of mutual benefit.

On paper, the Agreement goes beyond most of the formal agreements on the introduction of new technology that exists in the private sector (e.g. Beardon, 1983). It provides for the notification and consultation with the PSA, prior to the introduction of any VDUs. As well as prior notification of any proposals, the PSA is to be consulted after the initial assessment and preliminary approval stages are completed. This consultation will involve making available as much relevant information as possible, and giving the Association sufficient time to respond before any final decisions are made. The Agreement also covers the redeployment and retraining of affected workers, worker health and safety, and the work environment.

An SSC circular memorandum to Permanent Heads (States Services Commission, 1981), released just after negotiations were completed, instructed departments to comply with the Agreement (although variations can be negotiated in special circumstances). The processes involved have become formalised. VDU purchasing programmes are required to allow adequate time for consultation to occur, and proposals to introduce or extend VDU equipment must attend to the staff-related issues specified in the Agreement. It appears then that management's discretion in introducing this type of technology is limited by the Agreement. In theory, VDUs, including word processors, cannot now be introduced into government offices without the affected workers and their union being first consulted, and without any consideration of the effects on staff and their working environment.

In practice, however, management's discretion is not entirely fettered by the Agreement. For example, there need be no notification of a proposal when a system is being planned (the Agreement specifies only that "... the Association will be consulted after the initial assessment and preliminary approval stages have been completed"), yet it is at the design stage where the inputs of the union could be most effective in determining the nature of the work and the work environment. Also, unless the employees affected actively respond to proposals and fully involve the union, the PSA can have little or no control over the deployment of VDUs in individual workplaces. The Agreement can only work if the PSA is kept fully informed and if employees are prepared to take collective action to enforce compliance with its provisions. Finally, although the Agreement does 
make provision for the redeployment of displaced staff (i.e. it provides for individual job security), it cannot deal with any loss of jobs or job opportunities. As West (1982) has put it “. . . 'no redundancy' agreements simply redistribute unemployment to school leavers, as the unions have emphasised, and also to married women returnees to the labour force."

\section{Discussion}

This paper has outlined the transformation of office work that has occurred in the New Zealand Public Service since the late 19th century. Two waves of technological change in the office have been identified. The first wave - the original introduction of machines - facilitated the separation of "mental work" (carried out by administrative workers) from "manual work" (carried out by detail workers such as typists). The second wave - the advent of automated information processing - is now beginning to affect the work of some office workers in the Public Service, but the full development of this technology (the "automated office") has the potential to transform all office work.

The case study illustrates both the relevance of Braverman's explanatory framework and some of its weaknesses. The weaknesses identified here centre around the 3 themes previously noted, each of which will be examined in the following discussion.

\section{Bureaucracy and the managerial problem of control}

Unlike private sector ofganisation, most government departments are not concerned with profit-making or capital accumulation (some are though, e.g. State Insurance), which are considered by Braverman to dominate and shape the nature of work in a capitalist economy. However, public sector organisations are concerned with efficiency (and are accountable to Government for this), and with predictability and reliability of operation. The labour power of public servants is a commodity, as is the labour power of employees in the private sector, to be bought and sold in the market. The conflict of interests between employers and employees that exists in private sector organisations also exists in the public sector, and reflects a discrepancy between what can be bought in the market (labour power) and what is needed to carry out the functions of a department (labour):

These basic relationships ... reveal both the basis for conflict and the problem of control at the workplace. Conflict exists because the interests of workers and those of employers collide, and what is good for one is frequently costly for the other. Control is rendered problematic because, unlike the other commodities involved in production, labour power is always embodied in people, who have their own interests and needs and who retain their power to resist being treated like a commodity. (Edwards, 1979, p. 12).

Put another way, problems are likely to arise when people are used as means. Watson (1980) identifies a basic paradox in this : the various means that managements use to achieve organisational goals do not necessarily facilitate the efficient (or reliable or predictable) achievement of those goals, for the means include people who have goals of their own and these may not be congruent with those of management. For this reason, productive enterprises have had a tendency to make themselves as independent as possible of the human factors of production (Rada, 1980). One strategy is to seek to increase managerial control over the work process and the people involved in it, another is to remove people entirely from the production process (as in automation).

The notion of control (i.e. the ability of managers to obtain desired work behaviour from employees) is central to an analysis of the labour process. When government departments employed only a few workers and the work performed was relatively straightforward, as in the mid-19th century, direct face-to-face control was adequate to achieve the desired output. But as departments grew and diversified, and as the role of government 
became more complex and dependent on technical expertise, simple control was no longer sufficient and other forms of control became necessary. Braverman maintains that managerial control in enterprises under monopoly capitalism is achieved through the application of Taylor's principles of "scientific management" and it is these that have guided the application of technology in the workplace (i.e. production technology has been used as a means of control). By so doing, work has been progressively degraded and managerial dependence on worker co-operation has been reduced.

A greater degree of what Edwards (1979) has termed "technical control" could be provided by the introduction of word processing. This technology, as discussed earlier, offers the potential for increased managerial control over the copy transcription process. But to date, in no government department has there been the full development of a system of centralised word processing with full-time operators continually fed copy via centrallycontrolled automatic dictation machines. Word processing has generally been introduced as an extension of existing typing arrangements, rather than as a new system explicitly introduced to increase control over secretarial labour. The rationale underlying the introduction of this technology is more often that it improves the quality of output (e.g. by facilitating corrections of copy and by standardising copy formats), and it enables a greater productivity with fixed or reduced levels of labour inputs (an important feature given the present problems in government departments of fixed staff establishments).

Other strategies of control have been adopted by management, however, and in the public sector a system of bureaucratic rules and regulations has become the central form of control. Bureaucratic control is embedded in the social structure of the organisation in the form of explicit procedural rules (e.g. those set down in the Public Service Handbook which govern the day to day administration of departments, and including those which determine the organisation of copy transcription). These rules, aimed at avoiding arbitrary action, limit the discretion and initiative of individual employees (Mouzelis, 1967). Thus is created a unified "system of control" (Edwards, 1979), consisting of the elements of direction (which determines by whom and how work is to be performed), evaluation (the procedures, including personal assessment and office inspection, by which the performance of individuals and units is evaluated), and discipline (the imposition of rewards and sanctions to ensure compliance with managerial directives).

In a patriarchal society, forms of control which are specifically patriarchal may be employed by managements. Relations of male domination and female subordination are a strong theme in clerical and secretarial work. Women in the office are subject to different forms of treatment, even within a system of bureaucratic rules, from their male counterparts:

\begin{abstract}
... women at the lower ranks of the hierarchy, without the promotion incentives which are presented to male office workers, and employed as a means of securing their loyalty and hence devotion to duty, are encouraged through other ways. Flattery and praise, the engendering of a sense of indispensibility, as well as an underlying, albeit sometimes explicit sexual innuendo, are all forms of patriarchal control. As in society generally, they are encouraged to fulfil their roles as 'real women'. (Barker and Downing, 1980 p. 74).
\end{abstract}

Thus, a number of control strategies may be used simultaneously within the workplace. In the Public Service the over-arching framework is provided by a system of bureaucratic rules and regulations based on legislation, but within this other forms of control such as simple control or patriarchal control - may be employed.

\title{
The segregation of office work by sex
}

An area that is inadequately covered by Braverman is that of gender and work. This is a serious weakness for "gender is fundamental to the way work is organised; and work is central in the social construction of gender" (Game and Pringle, 1983, p. 3). It is a par- 
ticular weakness with respect to any study of office work, for women now make up the majority of the office workforce.

In the Public Service, as in the private sector, there is a sexual division of labour in the office. Office work is segregated by sex both vertically within occupations (i.e. very few women are employed in the executive grades of the executive/clerical occupational class, the great majority are employed in the basic grade clerical positions), and horizontally (i.e. the "service" office occupations of typist, office assistant, and data entry operator are "female occupations" as they are almost exclusively staffed by women). On average women are paid less than men as they predominate in the lower-paid grades and occupations, and they often have limited career prospects. For example, typists may aspire to senior supervisory positions over other typists, but rarely (if ever) do they achieve the executive positions which are concerned with the management of secretarial services. In the Public Service, typists may progress up the grades in the Typing Occupational Class, but only rarely do they transfer to the Executive/Clerical Occupational Class and thence to managerial positions.

But women employees are not only disadvantaged in terms of their remuneration and career prospects. The ideological distinction of "women's work" from "men's work" has a marked impact on the perceptions of the skills involved. The skill content of any job which is labelled as women's work tends to be devalued. This can be seen from the devaluation of the skill of shorthand writing, on which a high premium was placed when it was a specialised clerical function performed by males. As this skill was absorbed into the typists' function (to produce the shorthand-typist), it became devalued and it now only has a premium within the typists' occupation.

The concept of skill is a social construct: typing requires considerable manual dexterity and takes time and training to perfect, but nevertheless is valued less highly than many other clerical tasks. Objectively, word processing obviates the need for many of the traditional typists' skills such as shorthand writing and the formatting and layout of work. With the full development of the office automation technology, many of these skills will become completely redundant, including (with the introduction of typewriters capable of transcribing speech, or "talk-writers") keyboard skills. But, at the beginning of this second wave of technological change, word processing in the Public Service is seen, and is treated as, an extension of the traditional skills of typists. As the trends in the technological development become more obvious, this perspective will probably change.

\section{Technological change as a political process}

A major omission from Braverman's analysis is the resistance of workers to management's attempts at gaining greater control over the labour process, and that because of this managements may adopt other strategies to achieve their objectives (Friedman, 1977). For example, in the recent managerial literature on managing technological change in the office, a "humanistic" approach has been proposed (e.g. Driscoll, 1982), which seeks to gain pay-offs in both the productivity and job satisfaction of office workers. Resistance may be at the unorganised individual level, or it may be at the collective level. Although the first wave of technological change in government offices met with no collective opposition, the second wave has been the subject of considerable negotiation. There is thus a "political dimension" (this includes the processes of bargaining, negotiation, accommodation, etc., which occur between management, employees and their unions) to the introduction of new technology (Wilkinson, 1983).

There can be limits to the bargaining stance adopted by the workforce however. In the situation described here, the PSA could not prevent the introduction of the new technology, but instead has sought to influence its deployment. The attention has focussed on protecting the interests of those who are directly affected by the new technology. In the case of word processors this has been the Typing Occupational Class, and 
the efforts have aimed at preventing any erosion of their existing position. Although the activities of the PSA have placed some constraints on managerial prerogative, this prerogative is not entirely fettered, for the new technology is being introduced, the nature of office jobs is changing and job opportunities (at least) are being lost.

This paper began by noting that Braverman's perspective may not be adequate as an explanatory framework. At the detailed level of the individual case study, as for example in the case of office work in the Public Service, Braverman's analysis does appear to have a number of weaknesses. However, at the general level, Braverman's identification of the broad long-term tendencies to progressively degrade work in capitalist economies does seem to have validity. Word processors represent only the beginning of the second wave of technological change in the office. The technology needed to create the "automated office" already exists, and if this is adopted it could have a significant impact on the work of all office employees and could eliminate entirely the need for many lower-level employees. At present the new office technology is not being used to its full potential in the Public Service, but as the technology develops further and becomes more widely available, as the pressures on the Public Service to perform more effectively and efficiently become greater, it is likely that this potential will be realised. The long-term effects of technological change on office work could well be those predicted by Braverman.

\section{References}

Adler, M (1973) The writing machine London, Allen and Unwin.

Anderson, G (1976) Victorian clerks Manchester, Manchester University Press.

Barker, J and Downing H, (1980) Word processing and the transformation of the pattriarchal relations of control in the office Capital and Class 10 (Spring): 64-99.

Beardon C (1981) Restructuring the workforce: new technology and office jobs A paper presented to the New Zealand Geography Conference, Wellington, 27 August.

Beardon, C (1983) Computers and industrial relations: the New Zealand experience The Australian Computer Journal 15(4):140-144.

Beechey, V (1979) Labor and monopoly capital - notes towards a Marxist feminist critique University of Warwick, Sociology Department (mimeograph).

Beeching, W A (1974) Century of the typewriter London, Heinemann.

Braverman, H (1974) Labor and monopoly capital New York, Monthly Review Press.

Brocklesby, J (1983) Industrial relations and the capitalist labour process New Zealand journal of industrial relations 8(3): 223-232.

Burawoy, M (1978) Toward a Marxist theory of the labour process: Braverman and beyond Politics and Society 8(3-4):247-312.

Couchman, P K (1983) The introduction of word processors into DSIR Head Office Background notes on a case study (unpublished).

Driscoll, J W (1982) How to humanize office automation Office: Technology and People 1(2):167-176.

Edwards, R (1979) Contested terrain London, Heinemann.

Elger, T (1979) Valorisation and "deskilling" : a critique of Braverman Capital and Class 7 (Spring):58-99

Freidman, A (1977) Industry and labour London, Macmillan.

Game, A and Pringle R (1983) Gender at work Sydney, Allen and Unwin.

Glenn, E N and Feldberg, R L (1979) Proletarianizing clerical work: technology and organizational control in the office. In Zimbalist, A (Ed.) Case studies on the Labor process New York, Monthly Review Press. 
Gregory, J and Nussbaum, K (1982) Race against time: automation of the office Office: technology and people 1(2):197-236.

Guiliano, V E (1982) The mechanisation of office work Scientific American 247(3): 124-134.

Hunt Commission (1912) A to J, Vol. IV, H-34.

Littler, C E (1982) The development of the labour process in capitalist societies London Heinemann.

Mouzelis, N P (1967) Organisation and bureaucracy London, Routledge and Kegan Paul.

Polaschek, R J (1958) Government administration in New Zealand London, Oxford University Press.

Public Service Association (1980) The new technology and health Research Discussion Paper No. 13.

Public Service Association (1981) The new technology and the employment of women Research Discussion Paper No. 15.

Public Service Association (1982) Visual display units: An agreement between the Public Service Association and the State Services Commission on the introduction of visual display units into the Public Service.

Public Service Association (1983) New technology and the Public Service Information Leaflet No. 7.

Rada, J (1980) The impact of microelectronics Geneva, International Labour Office.

Rhee, H A (1968) Office automation in social perspective Oxford, Basil Blackwell.

Robertson, J F (1974) Legislation and industrial relations in the Public Sector. In Howells, J M; Woods, N S and Young, F J L, (Eds) Labour and industrial relations in New Zealand Carlton, Pitman.

Smith, D F (1983) Occupational segregation amongst white-collar workers in New Zealand New Zealand economic papers 17: 37-49.

Spinrad, R J (1982) Office automation Science 215(4534): 803-813.

Stark, D (1980) Class struggle and the transformation of the labour process Theory and society 9:89-130.

State Services Commission (1980) Report on word processing in government Management Services Report.

State Services Commission (1981) Circular memorandum 1981/97: Introduction of Visual Display Units into the Public Service.

State Services Commission (1983) Personal communication.

Sutherland, R (1981) The automated office - why all the fuss? Interface November, 24-26.

Tapscott, I (1981) Office automation : a user-driver method New York, Plenum.

Uhlig, R P, Farber, D G and Bair, J H (1979) The office of the future New York, NorthHolland.

Waterhouse, S A (1979) Word processing fundamentals San Francisco, Confield.

Watson T J (1980) Sociology, work and industry London, Routledge and Kegan Paul. Weber, M (1964) The theory of social and economic organisation New York, Free Press. West, J (1982) New technology and women's office work. In, West, J (Ed) Work, women and the labour market London, Routledge and Kegan Paul. 
Wilkinson, B (1983) The shopfloor politics of new technology London, Heinemann.

Wood, S (1982) The degradation of work? London, Hutchinson. 